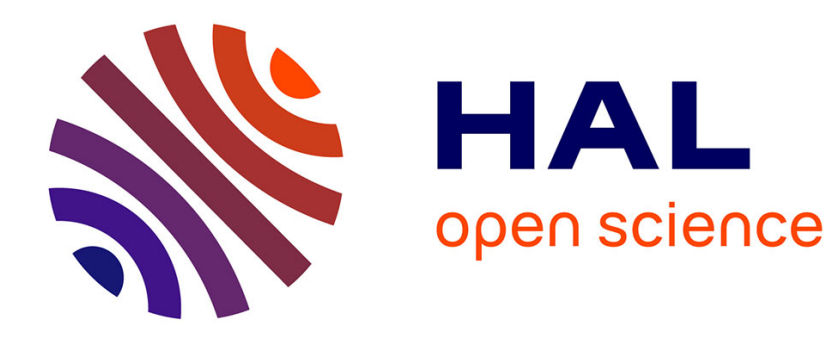

\title{
Investigations on Granular Ceramics and Ceramic Powder
}

\author{
L. Meyer, I. Faber
}

\section{To cite this version:}

L. Meyer, I. Faber. Investigations on Granular Ceramics and Ceramic Powder. Journal de Physique IV Proceedings, 1997, 07 (C3), pp.C3-565-C3-570. 10.1051/jp4:1997397 • jpa-00255554

\section{HAL Id: jpa-00255554 https://hal.science/jpa-00255554}

Submitted on 1 Jan 1997

HAL is a multi-disciplinary open access archive for the deposit and dissemination of scientific research documents, whether they are published or not. The documents may come from teaching and research institutions in France or abroad, or from public or private research centers.
L'archive ouverte pluridisciplinaire HAL, est destinée au dépôt et à la diffusion de documents scientifiques de niveau recherche, publiés ou non, émanant des établissements d'enseignement et de recherche français ou étrangers, des laboratoires publics ou privés. 


\title{
Investigations on Granular Ceramics and Ceramic Powder
}

\author{
L.W. Meyer and I. Faber \\ Technical University Chemnitz, Faculty Mechanical and Processing Engineering, 09107 Chemnitz, \\ Germany
}

\begin{abstract}
For brittle materials - like ceramics - its proved that the strong shock front shortly after impact loading create a rapid damage propagating in the ceramic. Therefore it is necessary to determine the mechanical properties of pulverised or pre-cracked material under high hydrostatic pressure. In a first step aluminium oxide powder as well as three types of ceramic fragments $\left(\mathrm{Al}_{2} \mathrm{O}_{3}, \mathrm{TiB}_{2}, \mathrm{~B}_{4} \mathrm{C}\right)$ were investigated by means of a confined compression test. First results under quasistatic as well as dynamic loading and different hydrostatic pressures will be presented. For post failure characterisation scanning electron microscopy (SEM) was used.
\end{abstract}

\begin{abstract}
Résumé: Pour des matériaux fragiles et cassants - comme la céramique - on a montré que le front de choc juste après un chargement par impact crée un endommagement rapide qui se propage dans la céramique. Pour cette raison il est nécessaire de déterminer les propriétés mécaniques de matériaux pulvérisés ou préfissurés sous une pression hydrostatique élevée. Dans une première étape on a étudié l'oxyde d'aluminium en poudre ainsi que trois types de fragments de céramiques $\left(\mathrm{Al}_{2} \mathrm{O}_{3}, \mathrm{TiB}_{2} . \mathrm{B}_{4} \mathrm{C}\right)$ à l'aide d'un essai de compression avec confinement. Les premiers résultats pour des chargements tant quasi-statiques que dynamiques et différentes pressions hydrostatiques vont être présentés. Pour la caractérisation post-mortem des fractures on a utilisé la microscopie électronique a balayage.
\end{abstract}

\section{INTRODUCTION}

Up today usually the quasistatic and dynamic properties of pristine ceramics are used to describe impact events and to simulate dynamic loading history. On the other hand its well known that in a case of rapid impact loading the strong shock waves in front of a penetrator causes local failure and fragmentation of the ceramic target [1]. The confinement and inertia effects prevent a displacement of the generated particles and so the condition in front of a penetrator tip can be described as a fully dense and simultaneously cracked ceramic. This state can be reached experimentally by shock pressure [2] as well as thermal shock [3]. Also it's conceivable to use green bodies of compacted powder as model materials with respect of the lower density $[4,5]$ in comparison with real applications.

Up to now there are several publications dealing with this new research topic $[2,4,5]$. But there is an lack and simultaneously a great need of reliable experimental data as well as constitutive equations diverted from mechanical properties of granular ceramics under real impact conditions.

That's why the aims of these research are to develop a suitable test setup which allows the verification of different hydrostatic pressures and the determination of the compressive strength and failure behaviour of pre-fractured ceramic under high confining pressures as well as dynamic loading conditions. The long term goals are the improvement of finite element calculations by providing dynamic mechanical properties converted into constitutive equations of comminuted ceramics and the better understanding of failure mechanisms and protection performance of brittle materials. 


\section{MATERIALS AND TEST SETUP}

\subsection{Materials}

The investigated materials were fragments of $\mathrm{Al}_{2} \mathrm{O}_{3}$ (named $\mathrm{B} 600$ ), $\mathrm{TiB}_{2}$ and $\mathrm{B}_{4} \mathrm{C}$ as well as a $\mathrm{Al}_{2} \mathrm{O}_{3}$ powder (similar to the chemical composition of $\mathrm{B} 600$ ) for comparison purposes. The irregular formed fragments are recovered from ballistic experiments (plate impact tests) with impact velocities in the range of 225 to $325 \mathrm{~m} / \mathrm{s}$ [6]. The particle size was measured by sieve analysis and can be described with a logarithmic distribution. Average particle size varies between $1000 \mu \mathrm{m}$ for $\mathrm{Al}_{2} \mathrm{O}_{3}, 1300 \mu \mathrm{m}$ for $\mathrm{B}_{4} \mathrm{C}$ and 2000 um for $\mathrm{TiB}$.

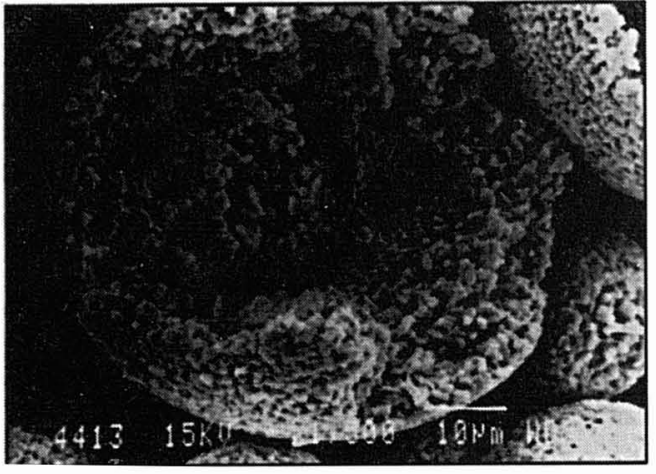

Alumina powder with a purity of $98 \% \mathrm{Al}_{2} \mathrm{O}_{3}$ was used in a pre-compacted condition of $50 \%$ density. This is advantageous to avoid a large displacement of the punch and to reach a similar loading level like in case of ceramic fragments. In the initial state the powder consists of homogeneously formed spherical granules with an average diameter of $80-100 \mu \mathrm{m}$ in which every sphere is composed of small grains with $0,5-2 \mu \mathrm{m}$ diameter (Figure 1).

Figure 1 Initial state of $\mathrm{Al}_{2} \mathrm{O}_{3}$ powder

\subsection{Test Setup}

To determine the residual strength of particulated ceramics or powder a confined compression test was developed [4] under the assumption, that the strength of the ceramic particles is higher than a given confining pressure.

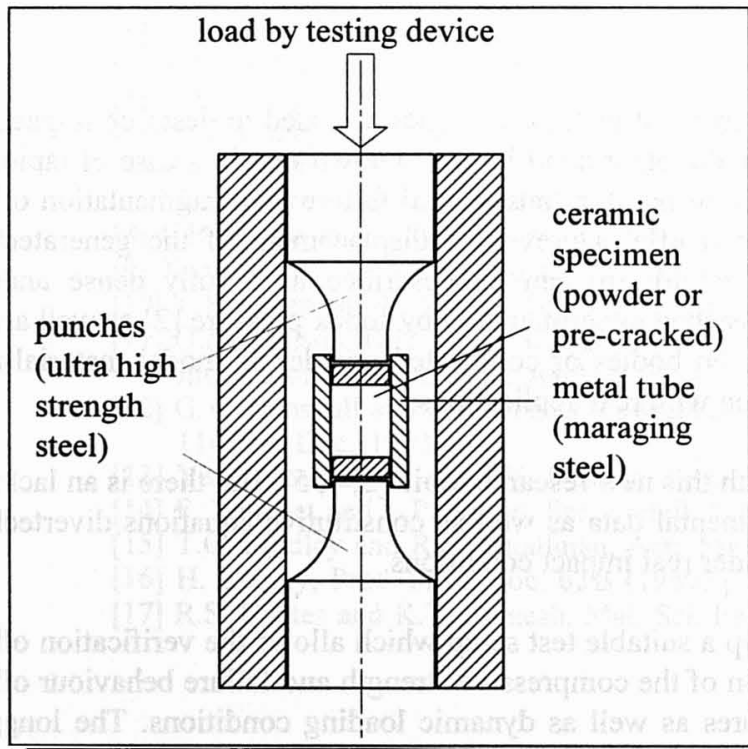

The fractured ceramic is surrounded by a metallic tube made of maraging steel and two discs are sealing the specimen among the punches. For this confined compression test the load is applied in axial direction in which one of the punches is fixed and the other one is movable. These technique is derived from soil mechanic and can be inserted in a hydraulic testing machine for quasistatic loading as given in Figure 2. A similar test setup was used in a drop weight tester for dynamic experiments. The main advantage of this configuration compared with soil mechanic procedures is the high hydrostatic pressure achievable. With the punches the specimen is compressed and densified ,elastically" as long as the occuring hydrostatic pressure does not exceed the internal elastic strength of the metal tube.

Figure 2 Test setup for confined compression test 
With increasing punch load the hydrostatic pressure finally leads to plastic flow of the metal tube and therefore the particles of the comminuted ceramics will or must glide on each other. To determine the „residual strength" of the comminuted ceramic particles a glide displacement of the amount of one mean diameter of the particles was used to define the corresponding axial stress at a certain tangential strain at the tube. Strain in circumferential direction (tangential strain) was measured by strain gages. Different combinations of wall thickness and strength of the tube material (solution-annealed and age-hardened) were examined. With this configuration hydrostatic pressures from 220 to $1240 \mathrm{MPa}$ are available. Hydrostatic pressure can be calculated corresponding to Equation 1 and Equation 2.

Equation $1 \quad p=\frac{1}{3}\left(\sigma_{1}+\sigma_{2}+\sigma_{3}\right) \quad$ Equation $2 \quad p=\frac{1}{3}\left(\sigma_{\text {axial }}+2 \sigma_{\text {radial }}\right)$

The great advantage of this method is the possibility of calibration by means of a nearly hydrostatic behaving material, for instance rubber. The different conditions of tube material and the varying wall thickness were calibrated in this way. Through the calibration its known which axial pressure of the punch generate a certain strain level at the metal tube - called radial pressure (Equation 3). This is required for calculation of the residual strength of ceramic fragments or powder (Equation 4).

Equation $3 \quad \sigma_{\text {radial }}=\frac{3 p-\sigma_{\text {axial }}}{2} \quad$ Equation $4 \quad \tau=\frac{\sigma_{\text {axiat }}-\sigma_{\text {radial }}}{2}$

Figure 3 and Figure 4 show the results of calibration for quasistatic and dynamic experiments and different conditions of tube material.

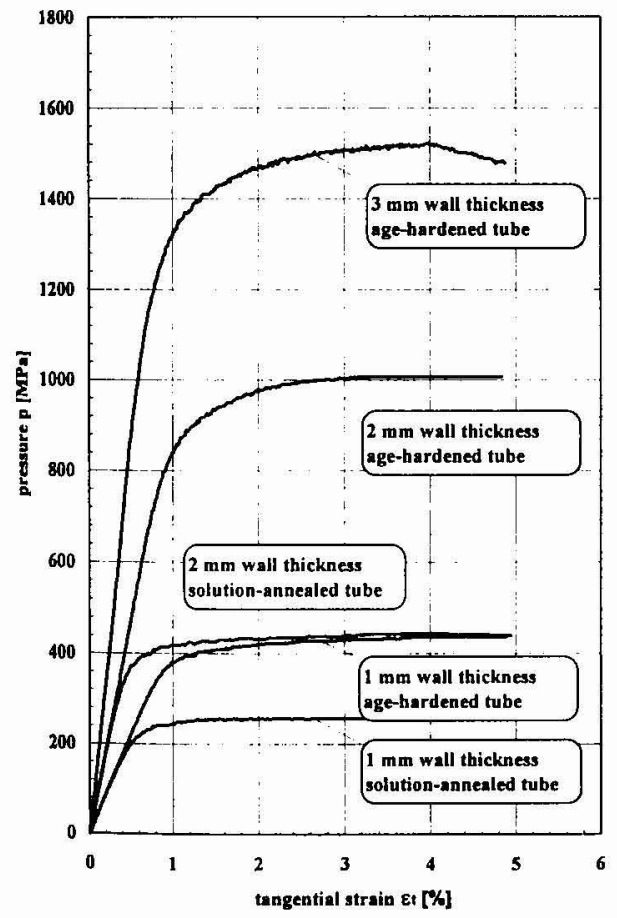

Figure 3 Calibration curves for quasistatic tests

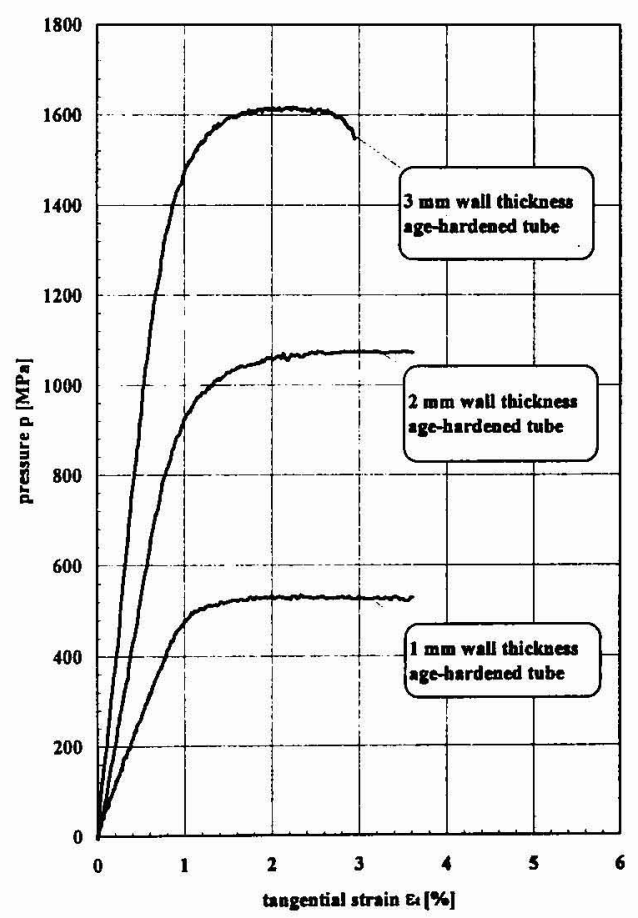

Figure 4 Calibration curves for dynamic tests 
These curves are basic elements of further tests. The slope of the elastic part of all curves corresponds to theoretical behaviour of thick-walled tubes under internal pressure [4]. This result confirms the hydrostatic behaviour of the selected rubber type, at least up to a pressure of $1400 \mathrm{MPa}$. With ceramic particles in the metal tube instead of rubber higher axial forces are needed to reach the same hydrostatic pressure, which is related to the material behaviour of the ceramics.

\section{RESULTS AND DISCUSSION}

The results of granular ceramics are illustrated in Figure 5 to Figure 7. Its clearly visible that the residual strength of fragments as well as compacted powder depends on the hydrostatic pressure. In all cases there was measured an increase of residual strength with rising hydrostatic pressure (Figure 5 and Figure 6). The alumina powder shows a different behaviour in comparison with fragments. The residual strength exhibits a weaker dependence on increasing hydrostatic pressure. That's caused by the morphological differences and the lower ability of energy dissipation. The difference to former results [4] is attributed to a lower friction in the new setup, shown in Figure 2. The investigated fragments shows an appreciable higher ability of energy dissipation caused by formation of new surfaces by fracture processes [7] than the ceramic powder. Due to fracture initiation and internal friction the irregular formed fragments show a considerable steeper increase of residual strength but simultaneously a significant higher scatter in the results. Therefore, as usual with ceramics, statistical methods have to be used in practice.

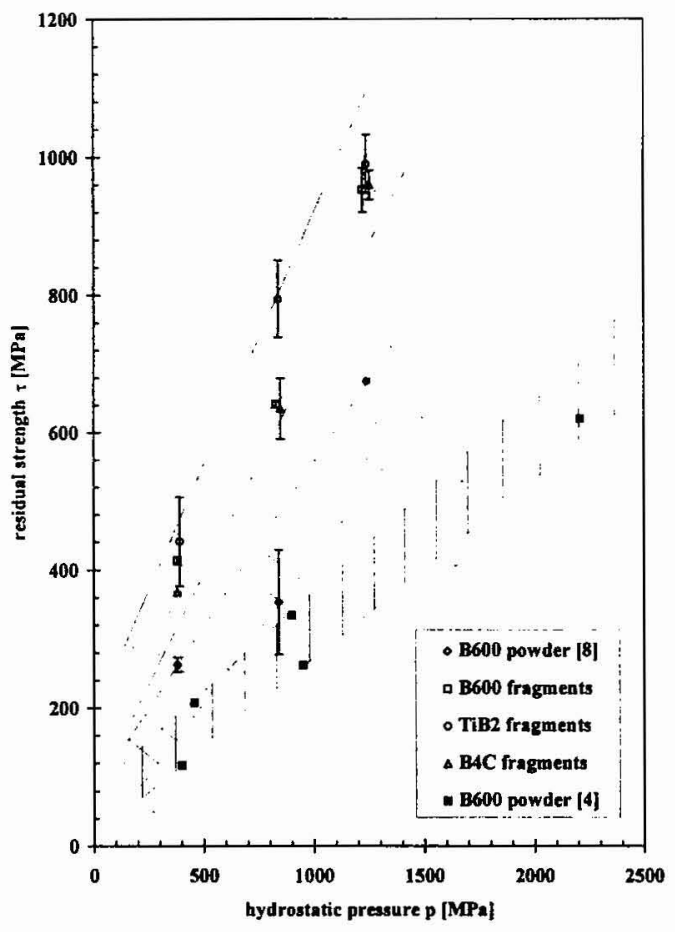

Figure 5 Residual strength versus hydrostatic pressure (quasistatic experiments)

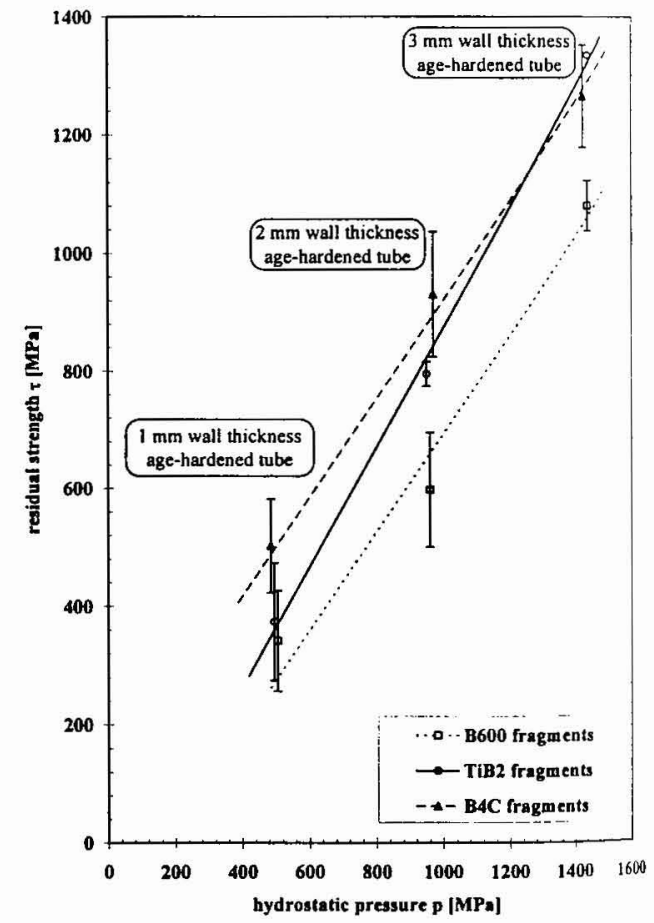

Figure 6 Residual strength versus hydrostatic pressure (dynamic experiments) 
First results of dynamic confined compression tests are illustrated in Figure 6 and 7. For all investigated fragments a significant increase of residual strength with rising strain rate is determined. Boron Carbide and Titanium Diboride show the steepest increase which is comparable with results of monolithic ceramics [8] under high strain rates.

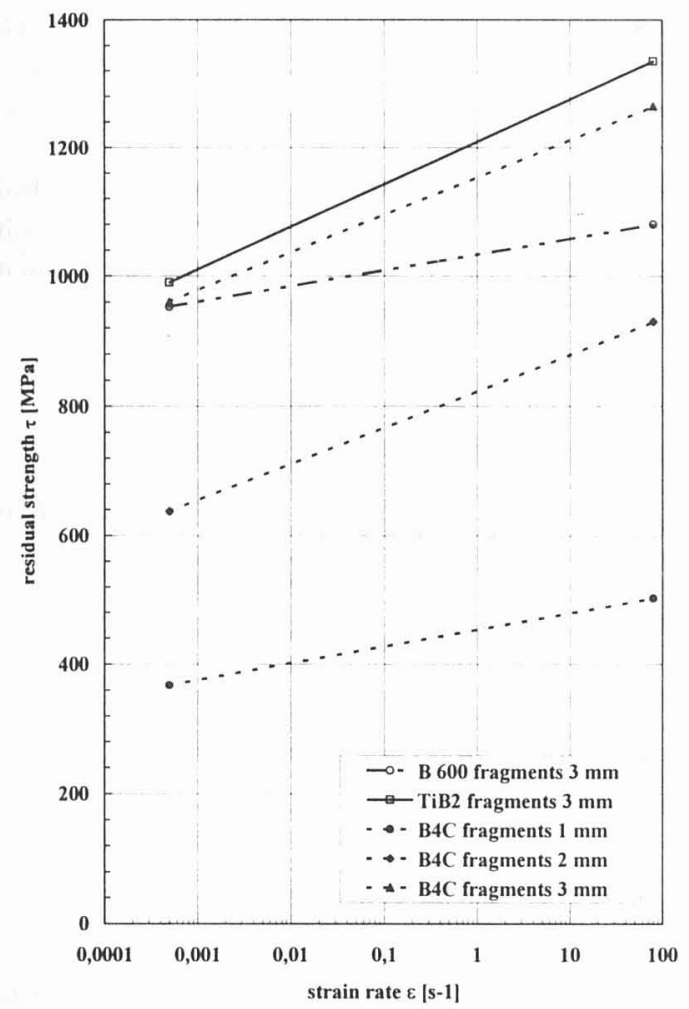

Figure 7 Residual strength versus strain rate

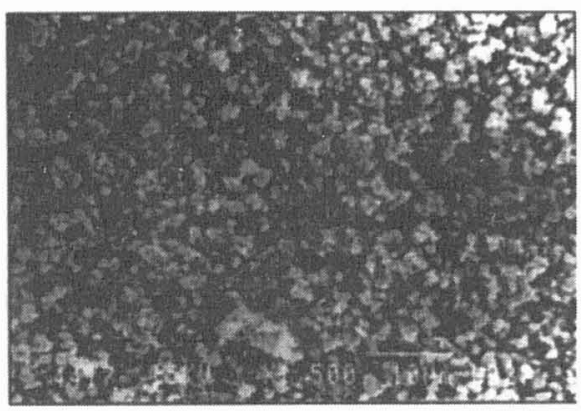

Figure 8 Microstructure of $\mathrm{Al}_{2} \mathrm{O}_{3}$ powder after testing

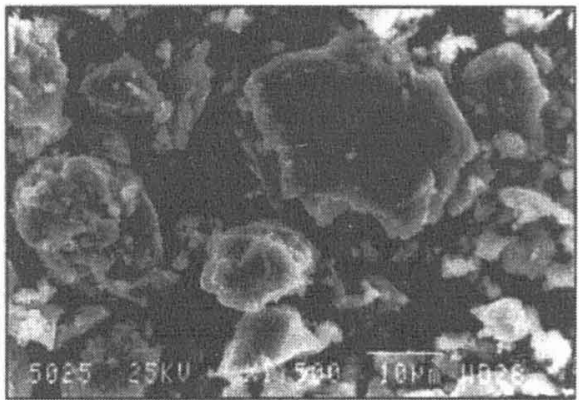

Figure 9 Microstructure of $\mathrm{Al}_{2} \mathrm{O}_{3}$ fragments after testing

The SEM-examinations of microstructure of $\mathrm{Al}_{2} \mathrm{O}_{3}$ powder and fragments after the confined compression test are given in Figure $\mathbf{8}$ and $\mathbf{9}$. It can be seen that the powder in comparison with the initial state (Figure 1) is fragmented into small particles with an average diameter of about 1-2 $\mu \mathrm{m}$ (Figure 8). This condition is already reached after a comparatively small loading. The ability of energy dissipation is smaller than in case of the ceramic fragments. This is caused by an early fracture of the spherical granules and a soon compacting and densification up to $85 \%$.

After testing the fragments show a considerably smaller particle size in comparison with the initial state but there is no visible difference between quasistatic and dynamic tests (Figure 9). Many transcrystalline cracks and a great amount of fine-grained fragments have been found. With that its proved that energy dissipation of fragments is caused by the formation of new surfaces. Reached densities are in the range of 50 to $70 \%$ dependent on the maximum load and wall thickness as well as structure condition of the metallic tube. 


\section{CONCLUSIONS}

With the confined compression test its possible to determine pressure dependent mechanical characterisation of comminuted ceramics. By variation of the surrounding tube material the definite adjustment of hydrostatic pressures is guaranteed. It could be proved that ceramic fragments under a high confining pressure achieve a considerable capacity of residual strength and energy dissipation. In comparison with the calibration tests with rubber more than the two times higher axial force is required to create the same hydrostatic pressure ore strain level in the tube material. Also there are tendencies that in case of impact loading the energy dissipation of pre-cracked ceramic is much higher than in quasistatic case.

As another result the significant dependence of residual strength from hydrostatic pressure is confirmed. Further experiments should be done with higher confining pressures and different levels of strain rate to provide constitutive equations based on real pressure-dependent properties of pre-cracked ceramics and to improve the knowledge about failure mechanisms and properties of brittle materials.

\section{Acknowledgements}

The authors are grateful to Mr. Nahme (Ernst Mach Institute, Weil a. Rhein, Germany) for delivery of ceramic fragments and useful discussions as well as Mr. Kinderling for creation of test setup basics.

\section{References}

[1] Stassburger, E.; Senf, H.; Rothenhäusler, H.: „Fracture propagation during impact in three types of ceramics", Journal de Physique III, Vol. 4, Septembre (1994), C8-653

[2] Zurek, A. K.; Hunter, D. A.: „Dynamic testing and characterization of pre-fractured ceramic"; American Institute of Physics (1994), p. 761-764

[3] Müller, T.: „Einfluß einer thermischen Schockbelastung auf die mechanischen Eigenschaften monolithischer $\mathrm{Al}_{2} \mathrm{O}_{3}$-Keramiken", Diplomarbeit, TU Chemnitz (1995)

[4] Meyer, L. W.; Kinderling, U.; Faber, I.: „Behaviour of granular ceramics under high hydrostatic pressure", IFAM report 6/1995

[5] Horsfall, J.; Iremonger, J.; Lumley, R. V.: „Projectile penetration trough comminuted ceramic“, $16^{\text {th }}$ Int. Symposium on Ballistics, San Francisco, CA, 23.-27.09.1996, p. 523

[6] Nahme, H.: „Dynamisches Materialverhalten verschiedener Keramiken bei Planar-Impact-Belastung", Presentation at IFAM, Bremen, 26.04.1994

[7] Fischmeister, F.; Arzt, E.: „Densification of powders by particle deformation“, Powder Metallurgy (1983), vol. 2, no. 2, p. 82-88

[8] Meyer, L. W.; Seifert, K.; Faber, I.: "Correlation between mechanical behaviour and ballistic performance of ceramics“, Proceedings $2^{\text {nd }}$ International Symposium on Impact Engineering, Chinese Journal of Mechanics Press, Peking, 1996 